\title{
日本における鳥類標識調査成果文献リスト（1990 年以降） \\ 梶田学 \\ A List of Literatures Concerning Bird Banding Works Since 1990 in Japan
}

\author{
Manabu KaJTA
}

日本における烏類慒識調査は，公的な事業として行われているものであり，その成果も公的な報告 書として出版が行われているが，その一方で鳥類標識調查に従事するボランティアバンダーによって も独自に多くの成果が論文や報文として様々な媒体を通して発表されている.しかし，これらボラン ティアバンダーによる成果は，鳥類標識協会誌などの専門誌に掲載されたもの以外，目に留まる機会 が多くはなく，バンダー自身も同僚であるバンダーがどのような成果を公表しているのか知る機会 を得られない場合が多いここのような状況を改変し，椂々な媒体に発表された鳥類標識調査の成果の 活用を促進することを目的として，鳥類標識調查で得られたデータを基に書かれた論文や報文のリスト を作成した。ここでは, 1990 年以降に発表された文献を扱っている。また,リストに婲载した文献 の人手老容易にするために，掲載雑訫の発行元についての情報を文献リストの後に掲載してある.

な扰，鳥類標識調查の成果について記述した文献でも，以下のようなものは，リストから除いた１） 一般的な鳥類標識調查の紹介に留まっているもの，2）書籍，報告苦に掲载されているもの．3）日本 鳥類標識協会訫（発行：月本鳥類標識協会）など鳥類標識調查の成果老専門的に扱っている雑誌に揭 載されたもの，4）鳥類標識調查を併用している場合でも，カラーマーキングなど学術中請が必要な 調查が主となっているもの.

\section{1. 文献リスト}

各文献の情報は, 以下のように表示した。著者名 発行年. 文献タイトル. 掲載雑誌名 巻数（号数） 最初のページー最後のページ [備考 $]$.

\section{A}

有馬浩史・藤井恭恵・澤祐介・中西麻美 2006. 13 枚の尾妆を持つ異常なシロハラ Turdus pallidus の個体. Strix 24:193-196.

キーワード：文献，鳥類標識，日本。

Key words: Literatures, Bird banding, Japan. 
有馬浩史・花咲ゆり・太田貴大 2004. 京都芦生研究林におけるオオコノハズク Otus lempiji 幼鳥の 標傤記録. Nature Study $50(5): 11-12$.

有馬浩史・須川恒 2004. 冠島で繁殖するオオミズナギドリの鳴声と体サイズにおける相関性. 日本鳥 学会誌 $53(1): 40-44$.

C

Chiba, A., Komatsu, Y. \& Itoh, Y. 1991. A record of the Pallas's Willow Warbler Phylloscopus proregulus in Niigata Prefecture, with histological notes on some internal organs. Japanese Journal of Ornithology 40(1):27-31. [千葉胃・小松古蔵・伊藤泰大 1991. 新潟県で記録されたカラ フトムシクイとその器官に関する組織学的観察. 口本鳥学会誌].

Chiba, A., Murata, K., Mizuno, S., Honma, R, \& Sugimori, F. 2002. External features and molecular sexing of the anomalous Pintail, Anas acuta, found at Hyo-ko Waterfowl Park, Niigata Prefecture, Japan. Ornithological Science 1(2):167-170. [千葉晃・村田浩 一水野重樹 - 本䦌隆

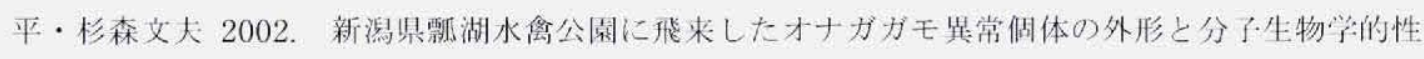
判别].

千葉一彦・村田野人・作山宗樹 2005. 岩于県釜石市におけるオオセッカ Locustella pryeri の捕獲䛉 録. 日本鳥学会鼔 $54(1): 56-57$.

F

藤井幹・ 丸岡禮治 2000. 神佘川県立自然保護センタ一野外施設における鳥類標嬂調杳報告. 神奈川県立 自然保護センター報告 (17): 1-9.

深井宣男 1995. 渡良瀬遊水地における希少種の標識䛉録と注月寸べき回収例. Accipiter 1:1-6.

媣井宣思・人見澗 1996. オオセッカ疗木県初礼録. Accipiter 2:25-26.

媣井宣男・人見潤 1998. コホオアカ柄木県初䛉録. Accipiter 4:39-41.

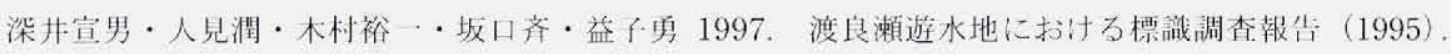
Accipiter 3:7-14.

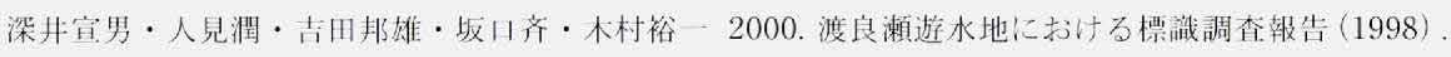

Accipiter 6:7-12.

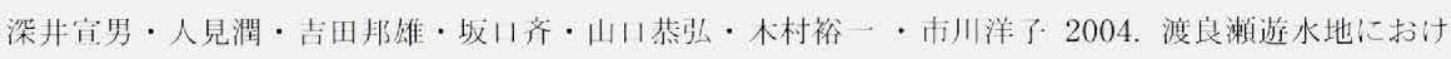
る㯲傤調查報告（2003） Accipiter 10:43-49.

深井宣男・英谷辰朗・山口恭弘・吉田邦雄 2002, シベリアアオジ Emberiza spodocephala spodocephala の杯朴県標識初記録. Accipiter 8:19-23.

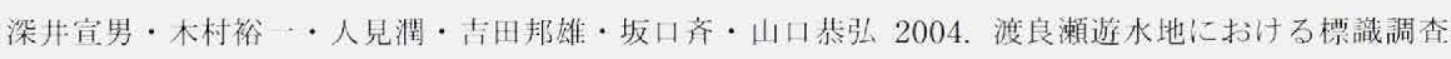
報告 (2002). Accipiter 10:37-42.

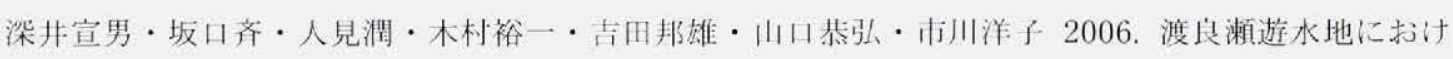
る標識調查報告（1990-2005）－秋期におけるホオジロ類，夜行性鳥類および潜行性鳥類の捕獲数 の季節変化一. Accipiter 12:27-36.

梁井宣男・古田邦雄・内川洋子 2004. アカマシコ Carpodacus erythrinus の標識乱録. Accipiter 10: 
$55-57$.

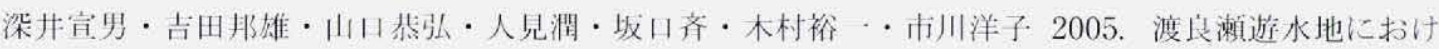

る標識調査報告 (2004). Accipiter 11:31-37.

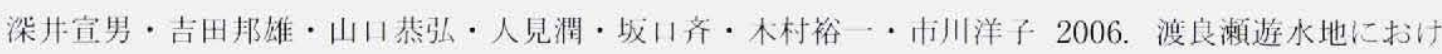

る標識調查報告（2005). Accipiter 12:21-26.

福田传弘・小高信彦・高田由紀子・山本泰志・内藤初夏 2001. イエスズメの日本初標識記録. 山階

鸟颣研究所研究報告 33(1):51-53.

祸阔堅造 1994. ツバメをバンディングして (4) 2 番了も同じ親が方てるのか? むくどり通信 (111): 2-3.

$\mathrm{H}$

原岛政し 1991.オジロビタキの越冬・槽識放鳥. Birder 5(6):42.

樋口孝城・広川涼子 2005. 北海道におおるオガワコマドリの䛉録. 山階烏類学雑就 37 (1):69-71.

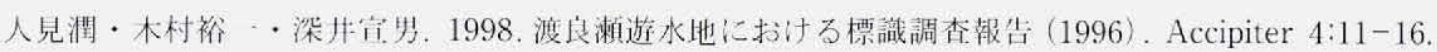

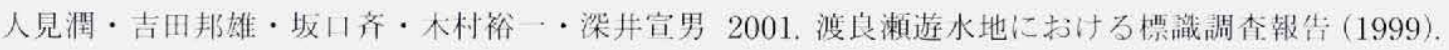

Accipiter $7: 17-23$.

広川淳子・浜出強・樋い孝城 2003。北海道曲部に㧍けるオオジュリンの㷌還調查。山階鳥類学雑綕 35

(1) $: 45-51$.

I

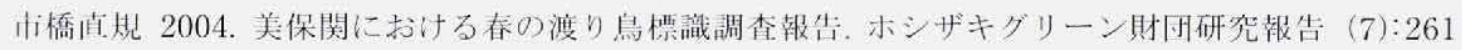
-270 .

井ノ浩之・吉四和人 2004. 標識調査に上り確認された徳岛県の鳥類. 徳岛県立博物館研究報告 (14):

113-128.

休あゆみ 1992. アオジ Emberiza spodocephala personata 幼烏（第 1 回冬妆）の性の識別につい

て.山階烏類研究所研究報告 $24(1): 1-12$.

不榢微 1990. 金沢巾におけるアカモズの亜種間交雑例. Strix 9:71-75.

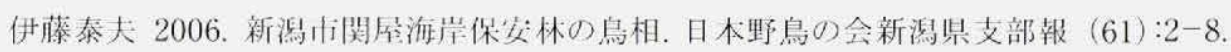

岩田篤志 2005. 鳥類標識調杳によるエソセンニュウ Locustella fasciolata の香川県初標識訕録. 否 川生物 (32): $9-12$.

K

梶田学・真野徹・佐藤文男 2002. 沖縄易に生息するウグイス Cettia diphone の二型についてー多変 量解析によるリユウキュウウダイスとタイトウウグイスの再部価一。山階鳥類研究所研究報告 33 (2):148-167.

片阙官彦 1993. ヤイロチョウの放鳥.鳥と自然 (71):14-15.

片岡宙彦 1997. 兵庫県に执けるシベリアジュリン (Emberiza pallasi) の䛉録, 鳥と自然 (86):14-15. 川路則反・早川嘉彦 1993. 札幌市で捕獲されたカラフトムシクイ. 森林保護（233）:5-6.

Bull. JBBA 19, 2007 
㐘池博 2005. 馬人橋（神奈川県平塚市）における八クセキレイの槽識調査 (2003-2004年)。Binos 12: 55-60.

木村裕一 一深井宣男・人見潤・吉田邦雄 1999。渡良瀬遊水地に拈ける標識調查報告（1997）. Accipiter $5: 15-22$.

小林繁樹・武下雅文・村本和之 1992. ツバメ Hirundo rustica の集団ねぐらにおける成鳥, 幼鳥比 の季節変化. Strix 11:219-224.

小林繁樹・内川一郎・内山由子 1998, 平生町田布施川河口周辺の野鳥. 山口野鳥 (30):56-100.

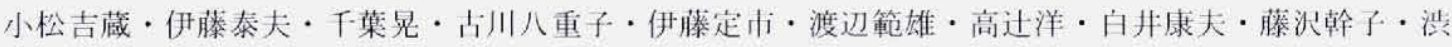

谷通夫・佐藤弘・瀬尾信雄・瀬尾澄子 1993. 標識調查からみた新潟巾海岸林に抢ける鳥類の渡り

の様相. 新渴県生物教育研究会誌 (28): 41-51.

Komatsu, Y., Satoh, H. Fujisawa, M. \& Chiba, A. 2004. Some Aspects of Seasonal Migration of the Bush Warbler Cettia diphone at Niigata City on the Coast of Central Japan, as Reveraled by Banding. Journal of the Yamashina Institute for Ornithology 36 (1):28-36 [小松古蔵・佐藤弘

・藤沢幹子・・葉昌 2004. 標識調查の結果からみた新潟けにおけるウクイスの渡りの様相㨫鳥 類学雑誌].

米田重玄・1: 木泰男 2002。環境庁織田山一級ステーションに戈ける槽識調查一 1973 年から 1996 年 に扔ける定最的モニタリング結果一.山階鳥類研究所研究報告 34 (1):96-111.

小杉和榯 1994. 利尻島沓形森林公園における鳥類標識调查（子報）。利尻研究 (13):3-6.

小杉和樹・田牧和広・佐藤雅彦 2005. 利尻島における鳥類の新分布および希少種の記録（3）。利尻研 究 $(24): 5-9$.

桑水流淳二 - 森田康大 - 丸野勝敏 - 廣森敏昭 - 行田義三 坂下泰典 - 中間弘 - 山元幸大 - 鮫島正道 溝口文男 2003. 宇治群岛の自然調查報告（その2)。鹿児島県立博物館研究報告 (22) : 1-58.

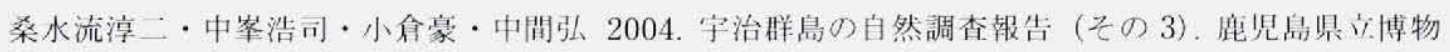
館研究報告 $(23): 1-20$.

\section{M}

前田茂雄 1999. ソウシチョウの愛知県初標識記録について. 西三河野鳥の会研究年報 2:19-20.

前田茂雄 2000.フクロウの移動記録について. 西三汇野鳥の会研究年報 $3: 24$.

前田茂雄 2001. 愛知県初記録のイイジマムシクイ. 西三河野烏の会研究年. 報 4:11-12.

前田茂雄 2003. 豊田巾渡合町における標識調査. 西三河野鳥の会研究年報 6:19-22.

前田茂雄・杉山時雄 2004. フクロウの移動記録について. 西三河野鳥の会研究年報 7:29-32.

三原学 2006. 九頭竜川河口の鳥類相 - 1999 年〜 2001 年の標識調查よりー. Ciconia 11:12-16.

三原学 2006. 2002 年福井県で標識されたシベリアジュリン.Ciconia 11:17-18.

三原学・大迫義人 2002. 福井県六吕師高原における鳥類相 IV - 1998～2000 年の標識調査結果よ り-. Ciconia 10:9-13.

三浦二郎 1993. 利尻島におけるチョウセンウグイス Horeites cantans borealis (Campbell) の Banding について. 利尻町立博物館年報 (12):31-32.

村上速雄 2004. えりも町におう少秋の小鳥類の標識調查. えりも研究（1):21-26. 
村上速雄 2006. えりも町に㧍ける小鳥類の秋の渡り調查 (2), えりも研究（3）:7-15.

$\mathrm{N}$

Nagata, H. \& Yoshida, H. 1997. Some notes on the wintering ecology of Japanese March Warblers, Megalurus pryeri, at two sites around lake Kasumigaura. Journal of the Yamashina Institute for Ornithology 29(1):50-56 [水田尚志・吉田保志子 1997. 霞ヶ浦のオオセッカの越冬生態. 山階鳥類研究所研究報告].

水田尚志・石本あゆみ 2000. 茨城県におけるサバンナシトド Passerculus sandwichensis の捕獲記 録. H本鳥学会誌 49(1):55-58.

永田尚志・鳥飼久裕・齐藤武馬 2002. 奄美大島におけるキタャナギムシクイ Phylloscopus trochilus の) 日本初標識記録. 日本鳥学会誌 51(1):87-91.

O

小畑義之 2003. 鳥類別秋の渡り時期一覧 98 年〜 02 年六甲山上鳥類標識調查の結果から.コウノトリ (133):14-23.

大迫義人 1992. 福井県六呂師高原における鳥類相 I - 1991 1992 年の秋冬期の呩識調査結果より - Ciconia 1:13-21.

大迫義人 1994. 福井県六吕師高原に拈ける鳥類相 II -1992 年度・1993 年度の標識调查結果より一. Ciconia 3:39-41.

大迫義人 1999. 福井県織田山鳥類観測ステーションにおけるカシラダカとアオジの捕獲個体数の変 動とその要因. Ciconia 8:9-20.

大迫義人.三原学 1998. 標識調查から得られた鳥類の外部計測值, 捕獲時期および生存日数. Ciconia $7: 7-12$

大迫義人・三原学 1998. 福井県六呂師高原における鳥類相 III $-1994 \sim 1997$ 年度の槽識調查結果 より-. Ciconia 7:25-27.

大迫義人・三原学 2002. 福井県大野巾平家平の鳥類相とその保全. Ciconia 10:15-24.

$\mathrm{S}$

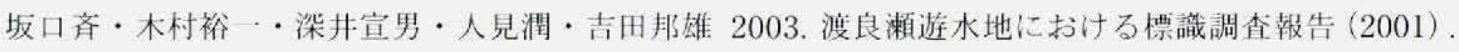
Accipiter 9:11-18.

作山宗樹 2005. 車力村岩木川河口部におけるマキノセンニュウの記録. 青森自然誌研究 (10):42. 笹原裕二 2000. 1999 年度春期「根上の松」古戦場でのバンディング. 石川野鳥年鑑 1999:71-72. 笹原裕: 2001. 2000 年春期「根上松」古戦場でのバンディング結果と観察記録. 石川野鳥年鑑 2000:67.

笹原裕二 2001. 2000 年秋期木場潟バンディング結果. 石川野鳥年鑑 2000:68.

笹原裕二 2002. 2001 年春期根上松古戦場でのバンディング結果と観察記録. 石川野鳥年鑑 2001:74 -75 .

笹原裕二. 2002. 2001 年秋期小松市木場潟でのバンディング結果. 石川野鳥年鑑 2001:76. 
笹原裕二. 2002. 秋期に小松怵場潟のヨシ原を通過するオオジュリンの渡りのルート. 石川野烏年鑑 2001:77-81.

笹原裕二 2002. 2001 年に石川県で行われた鳥類標識調查の概要. 石川野烏年.鑑 2001:83-85.

任藤理夫 1994. 函館巾における鳥類の渡りについて一鳥類槽識調査から一, 巾立崡館博物館研究紀要 (4) $: 1-32$.

Sato, M., Ogi, H., Tanaka, M. \& Sugiyama, A. 1997. Band-bellied Crake Rallina paykullii taken at Oshima Ohshima Island, Hokkaido, Japan. Journal of the Yamashina Institute for Ornithology 29 (2):102-107 [佐藤理大 - 小城春雄・田中正彦・杉山淳 1997. 渡島大岛で捕獲され たコウライヒクイナについて.川階鳥類研究所研究報告].

茂田良光 2003. 日本からの亜種チョウセンオオルリCyanoptila cyanomelana cumatilisの確实な初 記録. 山階鳥類研究所研究報告 $34(2): 309-313$.

岛田明英 1993. 西岡水源池烏類呩識調查一特にハシブトガラとコガラについてー。ワイルドライフ・ レポート $(15): 30-35$.

清水敏弘 2000. 秋期に求けるメボソムシクイの体重変化. 西三河野鳥の会研究年趣 3:11-14. 杉山時雄・前田茂雄 2004. 八リオシギの観察と捕獲. 西三町野烏の会研究年報 7:25-28.

$\mathrm{T}$

宫田勝 1991. 根公支打管内鳥類リス卜. 根空巾博物館開設淮備宔紀要（5):1-19.

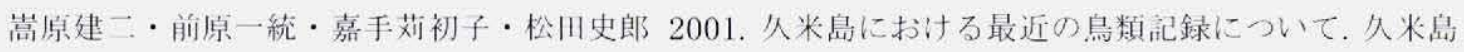
白然文化センター紀要 創刊号: 1-19.

武下雅文 1997. 九州北部におけるイワツバメの繁殖状沉. わたしたちの自然史 $(60): 4-6$.

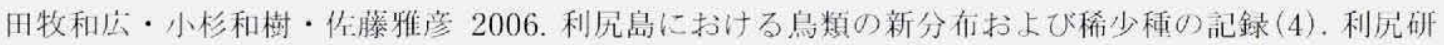
究 $(25): 33-36$.

Tojo, H.. Osawa, K. Terauchi, H. Kajita, M., Kajita, A. \& Watanuki, O. 2004. Invasion by White-browed Laughing Thrushes (Carrulax sannio) into Central Japan. Global Environmental Research 8(1):23-28 [White-browed Laughing Thrushes はカオジロガビチョウ].

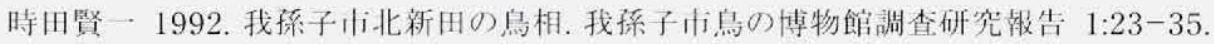
時田堅 1994. 我採子市北新卅の鳥相 (1993). 我採子市鳥の博物館調查研究報告 3:27-35. 時田堅 1996. 我棌子小北新田の鳥相追加種報告 (1994-1995). 我孫子小鳥の博物館調查研究報告 5:193-197.

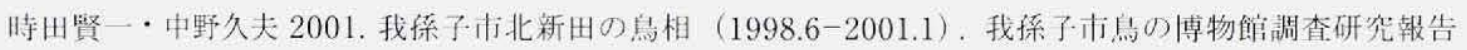
$9: 65-72$.

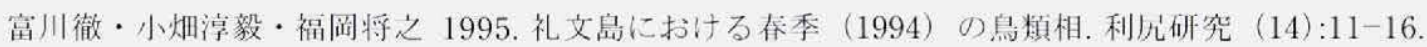
富沢星章・島田明英 1993. 西阊水源池飭台に飛来する鳥類の個体数調枯. ワイルドライフ・レボート (15) : 36-40.

$\mathrm{U}$

上野吉雄・茫木信・小柴正記・日比野政产 2004. 西中国川地におけるソウシチョウの生息状況. 高原 の自然史 $(9): 111-121$. 
上野古雄・保井浩・川本裕 1996. 広島県芸北町の鳥類. 高原の自然史 (1):291-393.

上野古雄・東常哲也・柾裕・日比野政彦・倣田知彦 1993. 西中国川地におおるシロハラ Turdus pallidus の繁殖. H本鳥学会誌 41(1):17-19.

馬川勝義 2005. 伊万里市長浜における小鳥類の渡り時期について.つばさ（223）:4-6.

W

脇坂英弥 1998. 斐阱川にお゙けるバンディングによる鳥類の渡り調査. ホシザキグリーン財団研究報告 (2): $1-6$.

脇呫英弥 2002. 泉根県におけるリュウキュウヨシゴイの初記録. Strix 20:181-183.

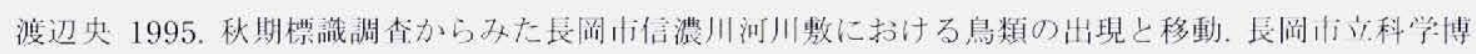
物館研究報告 $(30): 41-52$.

渡辺糺久雄 1991。札帨小に拈けるオオジュリンの標識記録。ワイルドライフ・レポート (12):22-27.

Y

Yamamoto, Y. \& Higuchi, H. 2004. First record of the Varied Tit subspecies Parus varius varius from Miyake-jima of the Izu Islands, central Japan. Journal of the Yamashina Institute for

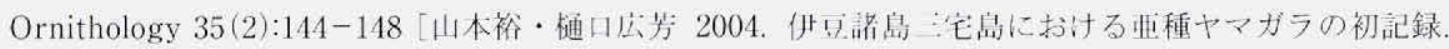
山階烏類学権誌了.

川根みどり 1996. シベリアジュリンとコジュリンの淀川での標識放鳥について. むくくどり通信（123） :8-9.

山根みどり 1997. 秋の渡り標識調查短信.むくどり通信 (127): 5 .

吉田一朗 2006. 2002 年に福井罢中池胃湿地で橧識されたマキノセンニュウ. Ciconia 11:19-21.

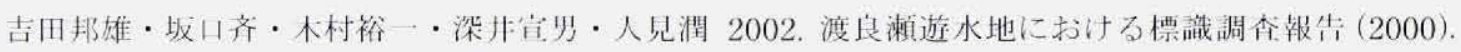

Accipiter $8: 1-7$.

2 . 文献掲械雑誌の発行元リスト

A：我孫子市鳥の博物館洞查研究報告 [発行: 我棌子市烏の博物館(千葉県)], Accipiter [発行:日本野鳥

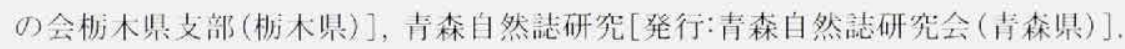

B : Binos [発行: 月本野鳥の会神余川支部(神奈川県)], Birder [発行：文・総合出版 (東京都) ].

C : Ciconia [発行:福井県自然保護センター(福井県)].

$\mathrm{E}:$ えも研究[発行:えりも町郷十資料馆ほろいずみ・水産の館 (北海道)].

$\mathrm{H}$ ：ホシザキグリーン財団研究報告 [発行:ホシザキグリーン斯団(白根県)].

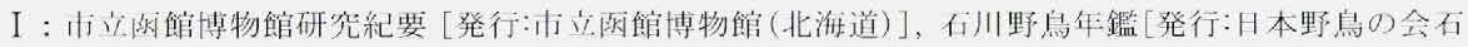
川支部(不川県) ].

J : Japanese Journal of Ornithology (日本鳥学会誌) [発行:日本鳥学会], Journal of the Yamashina Institute for Ornithology (小階烏類研究所研究報告) [発行:川階烏類研究所 (千葉県) ].

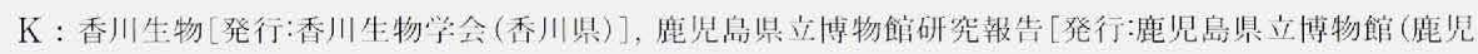
島県) ], 神奈川県文自然保護センター報告 [発行: 神奈川県立自然保護センター(神佘川県) ], 高原 
の自然史 [発行:芸北町教育委員会 (広島県)], コウノトリ [発行:日本野鳥の会兵庫県支部(兵㡷県) ], 久米島自然文化センター紀要 [発行: 久米島自然文化センター (蚛縄県) ].

G : Global Environmental Research [発行:国際環境研究協会(東京都)].

$\mathrm{M}$ ：むくどり通信[発行:日本野鳥の会大阪支部(大限府) ].

$\mathrm{N}$ ：長岡市立科学博物館研究報告 [発行:長岡市立科学博物館 (新潟県)], Nature Study [発行: 大阪自然 史博物館友の会 (大阪府) ], 根室市博物館開設淮備室紀要 [発行: 根室巾博物館開設淮備公(北海道) ], 日本鳥学会誌[発行:日本鳥学会], 日本野鳥の会新潟県支部報[発行:日本野烏の会新潟県支部 (新潟 県)], 新潟県生物教育研究会誌[発行:新潟県生物教育研究会 (新潟県) ], 西三河野鳥の会研究年報 [発 行:西二河野鳥の会 (愛知県) ].

O : Ornithological Science[発行:日本鳥学会].

$R$ : 利尼町立博物館年報 [発行:利尻町立博物館 (北海道)], 利尻研究 [発行: 利旮町立博物館(北海道)].

S：森林保護 [北海道森林保全協会 (北海道)], Strix[発行：日本野鳥の会(東京都) ].

$\mathrm{T}$ ：徳島県立博物館研究報告 [発行:德帛県立博物館(徳島県)],鳥と自然 [発行: 兵庫野鳥の会(兵㡷県) ], つばさ[発行:日本野鳥の会長崎県支部(長崎県) ].

W：ワイルドライフ・レポート[発行:エコ・ネットワーク(北海道)], わたしたちの自然史[発行: 北九 州自然史友の会(福岡県)].

Y : 山口野鳥 [発行:日本野鳥の会山口県支部 (山口県)],山階鳥類学雑誌 [発行:山階鳥類研究所(千葉県)], 山階鳥類研究所研究報告 [発行:山階鳥類研究所 (下葉県) ].

梶田学 kaji-m@m9.dion.ne.jp

于 603-8227 京都府京都市北区紫野北舟岡町 49

\section{Manabu Kajita}

49 Murasakino Kitafunaoka-cho, Kita-ku, Kyoto-shi, Kyoto, 603-8227 Japan 